\title{
Studi Komparasi Hasil Pengolahan Pasang Surut Dengan 3 Metode (Admiralty, Least Square dan Fast Fourier Transform) di Pelabuhan Malahayati, Banda Aceh
}

\section{Lintang Fauzia Ichsari*, Gentur Handoyo, Heryoso Setiyono, Aris Ismanto, Jarot Marwoto, Muh Yusuf dan Azis Rifai}

\author{
Departemen Oseanografi, Fakultas Perikanan dan Ilmu Kelautan, Universitas Diponegoro \\ Jl. Prof. Sudarto, SH Tembalang Tlp. / Fax. (024)7474698 Semarang 50275 \\ Email:lintangfauziai@gmail.com
}

\begin{abstract}
Abstrak
Pelabuhan Malahayati menjadi alur lintas serta tempat sandar bagi peti kemas domestik. Untuk menjalankan aktifitas pelabuhan secara optimal serta merencanakan pembangunan pelabuhan, pengetahuan mengenai tipe dan karakteristik pasang surut sangat penting. Pengolahan data pasang surut dengan berbagai metode dapat memberikan hasil yang berbeda-beda. Tujuan penelitian ini adalah untuk mengetahui karakteristik pasang surut dan komponen harmonik pembangkit pada lokasi penelitian, mengetahui perbandingan hasil pengolahan pasang surut dengan metode admiralty, least square dan fast fourier transform. Serta melakukan prediksi elevasi pasang surut dengan metode least square pada waktu setelah penelitian. Validasi hasil pengolahan pasang surut dilakukan dengan menghitung nilai RMSE hasil pengolahan metode least square terhadap data lapangan. Ketiga metode menghasilkan tipe pasang surut Pelabuhan Malahayati yaitu tipe pasang surut harian ganda. Metode admiralty menghasilkan 9 komponen utama pasang surut, sedangkan metode least square menhasilkan sejumlah 68 komponen. Sementara metode FFT digunakan untuk mengidentifikasi 21 komponen harmonik pasang surut Pelabuhan Malahayati. Didapatkan dominasi komponen harmonik pasang surut pada Pelabuhan Malahayati, yaitu komponen semidiurnal (M2 dan S2). Didapatkan nilai RMSE pada hasil pengolahan sebesar $32 \mathrm{~cm}$, sedangkan RMSE hasil prediksi sebesar $64 \mathrm{~cm}$. Perbedaan nilai formzhal kurang dari 0.02 sedangkan perbedaan nilai amplitudo masing-masing komponen pasang surut kurang dari 0.1 meter.
\end{abstract}

Kata kunci : Pasang surut, Admiralty, Least Square, Fast Fourier Transform, Pelabuhan Malahayati

\section{Abstract}

Malahayati Port serves as crossing lane and transit for domestic container ships. To carry out port activities optimally and design port development, knowledge of the types and characteristics of the tides in the location is very important. This study was to determine the tidal characteristics and harmonic components of the Malahayati Port, to compare the results of tidal processing using 3 methods (admiralty, least square and fast fourier transform) and to predict the elevation of tides after this study using the least square method. Validation on this study was done by calculating the RMSE between least square result and field data. All of the 3 methods resulted the Malahayati Port tidal type which was semi diurnal tide. The admiralty method produced 9 major components, while the least square produced 68 of tidal harmonic components. And the FFT is used to identify 21 harmonic components of the Malahayati Port. Obtained that the dominance of the tidal harmonic component at the Malahayati Port was semidiurnal component M2 and S2. Noted that the RMSE value between least square result and field data is $32 \mathrm{~cm}$, while the prediction RMSE is $64 \mathrm{~cm}$. Using 3 methods the Formzhal difference is less than 0.02 while the difference in the amplitude of tidal component is less than 0.1 meters.

Keywords: Tides, Admiralty, Least Square, Fast Fourier Transform, Malahayati Port

\section{PENDAHULUAN}

Sejak dahulu Pantai timur Sumatera cenderung memiliki potensi yang besar, mulai dari berbagai aktivitas politik, ekonomi, dan kebudayaan (Purwanto, 2017). Titik lokasi penelitian pasang surut berada stasiun pasang surut milik Badan Informasi Geospasial di bawah PT. Pelindo I Cabang Malahayati. Tepatnya di Desa Lamreh, Kecamatan Krueng Raya, Provinsi Aceh (Gambar 1). Lokasi penelitian juga merupakan pelabuhan yang melayani pelayaran dan menjadi sandar untuk peti kemas domestik. Dalam menjalankan aktifitas pelabuhan, pengetahuan mengenai tipe pasang surut 
dapat memberikan gambaran umum tentang berapa kali pasang atau surut, sehingga dapat memberikan acuan yang diperlukan pada lokasi penelitian untuk melaksanakan perencanaan pembangunannya. Selain itu, data pasang surut akan membantu menangani permasalahan yang sering timbul pada kolam pelabuhan, seperti pendangkalan (Rahmat, et al, 2017). Terdapat berbagai macam cara untuk melakukan pengolahan data pasang surut. Masing-masing metode akan memberikan hasil yang berbeda serta memiliki tingkat akurasi yang berbeda-beda pula. Dibutuhkan tingkat keakuratan atau minimnya nilai kesalahan pada hasil pengolahan guna menyatakan apakah hasil pemodelan dapat merepresentasikan kondisi perairan sebenarnya atau tidak (Syahputra dan Nugraha, 2016). Namun demikian, belum banyak diketahui perbandingan hasil yang diberikan maupun keakuratan model pasang surut dari metode-metode tersebut. Tujuan penelitian ini adalah untuk mengetahui karakteristik pasang surut pada lokasi penelitian dan komponen harmonik pembangkit pasang surut yang mempengaruhi pembentukannya. Serta untuk mengetahui perbandingan hasil pengolahan pasang surut pada stasiun Malahayati yang diolah dengan menggunakan berbagai metode, yaitu metode admiralty, Least Square dan FFT.

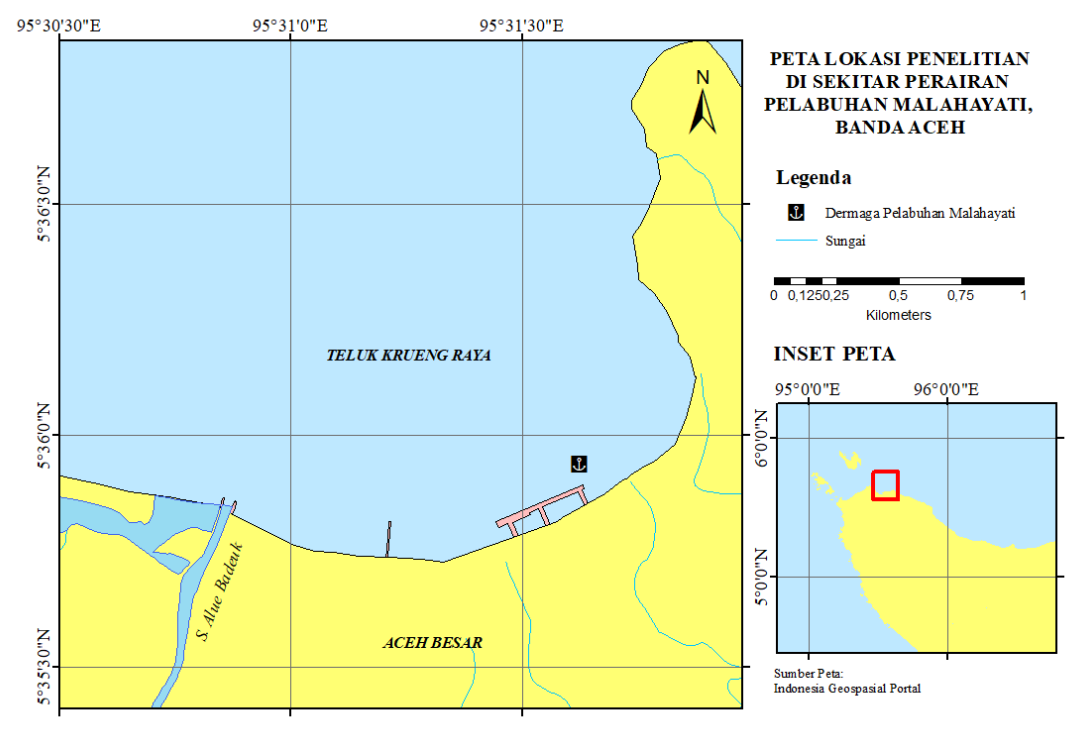

Gambar 1. Lokasi Penelitian Pelabuhan Malahayati, Banda Aceh

\section{MATERI DAN METODE}

\section{A. Materi Penelitian}

Data utama yang digunakan dalam penelitian ini merupakan hasil pengukuran pasang surut realtime oleh Badan Informasi Geospasial pada stasiun Malahayati, Banda Aceh. Lokasi penelitian terletak pada koordinat $5^{\circ} 35^{\prime} 50^{\prime \prime} \mathrm{LU}$ dan $95^{\circ} 30^{\prime} 35^{\prime \prime}$ BT. Panjang data yang digunakan meliputi 6 tahun (72 bulan) dengan interval waktu 15 menit, mulai dari tanggal 1 Januari 2013 pukul 00:00:00 sampai dengan 31 Desember 2018 pukul 23:45:00.

\section{B. Metode Penelitian}

Metode penelitian yang digunakan adalah metode eksperimen yang merupakan bagian dari metode kuantitatif, karena metode yang digunakan memberikan hasil yang dapat diterapkan untuk analisa pada wilayah lain. Data di dalam penelitian merupakan data yang dikumpulkan, diproses dan dianalisis berdasarkan masalah dan tujuan penelitian sesuai teori yang telah dipelajari. Pengolahan data pada penelitian ini dilakukan terhadap stasiun pasang surut di Malahayati, Banda Aceh, dengan menggunakan tiga metode (admiralty, least square dan Fast Fourier Transform) sehingga didapatkan karakteristik dan komponen harmonik pasang surut pada lokasi penelitian. 


\section{Pengumpulan Data}

Pengumpulan data pasang surut dalam penelitian ini diperoleh dari hasil pengamatan pasang surut realtime pada Stasiun Malahayati, Banda Aceh. Data tersebut merupakan data yang diukur langsung menggunakan perangkat tide gauge yang terpasang pada lokasi stasiun. Stasiun Malahayati sendiri terletak pada koordinat $5^{\circ} 35^{\prime} 50^{\prime \prime}$ LU dan 95 $30^{\prime} 35^{\prime}$ BT. Panjang data yang digunakan untuk lokasi stasiun mencapai 6 tahun dengan interval waktu setiap lima belas menit, mulai dari 1 Januari tahun 2013 pukul 00:00:00 sampai dengan 31 Desember 2018 pukul 23:45:00.

\section{Metode Admiralty}

Metode Admiralty merupakan salah satu dari metode harmonik yang digunakan untuk menghitung dua konstanta harmonik yaitu amplitudo dan beda fase dalam rentang waktu yang pendek (29 hari). Output yang dihasilkan dalam metode admiralty meliputi amplitudo (A) dan fase (g) dari setiap komponen pasang surut dan elevasi beberapa muka air penting. Komponen pasang surut hasil pengolahan metode admiralty meliputi 9 komponen utama pasang surut yaitu: M2, S2, N2, K1, O1, P1, M4, MS4, dan K2. Sedangkan nilai elevasi yang dihasilkan dari pengolahan data ini antara lain: MSL, HWL, HHWL dan LLWL. Dalam pengolahan lebih lanjut, nilai amplitudo (A) digunakan untuk menentukan nilai Formzhal (F), sehingga akan didapatkan tipe pasang surut pada lokasi penelitian.

\section{Metode Least Square}

Analisa Harmonik data pasang surut pada penelitian ini dilakukan dengan metode least square yang dikembangkan oleh Rich Pawlowicz pada tahun 2002, yaitu paket T_Tide. Data pasang surut pada lokasi stasiun yang telah diolah dengan menggunakan paket $T_{-}$Tide akan menghasilkan nilai kedudukan muka air yang berupa nilai LWL (Lowest Water Level), MSL (Mean Sea Level) dan HWL (Highest Water Level). Selain nilai-nilai tersebut, dapat diketahui pula waktu awal dan akhir pengamatan serta rentang waktu pengamatan sekaligus. Selain itu, pengolahan dengan paket $T$ _Tide ini juga menghasilkan nilai komponen pasang surut yang meliputi nilai amplitudo (A), fasa (g), serta nilai frekuensi dari masing-masing komponen pasang surut. Nilai amplitudo komponen pasang surut kemudian diolah untuk mendapatkan nilai formzhal (F) sehingga dapat diketahui tipe pasang surut dari lokasi penelitian. Di dalam paket $T_{-}$Tide juga tersedia tools untuk melakukan prediksi pasang surut pada lokasi, prediksi pasang surut dapat dilakukan pada waktu sebelum maupun sesudah waktu pengamatan.

\section{Metode Fast Fourier Transform}

Pengolahan data pasang surut menggunkan metode FFT bertujuan untuk mengubah sistem dengan fungsi yang kompleks menjadi penjumlahan dari sistem sederhana, dalam hal ini pasang surut akan dirubah menjadi penjumlahan fungsi sinusoidal. Pengolahan dengan metode FFT menghasilkan nilai komponen-komponen pasang surut yang telah ditentukan sebelumnya. Nilai komponen pasang surut tersebut meliputi nilai amplitudo (A) dan fase (g). Dari nilai amplitude tersebut kemudian akan diperoleh perhitungan nilai formzhal sehingga diketahui tipe pasang surut di lokasi penelitian.

\section{Prediksi Pasang Surut}

Metode prediksi pasang surut yang ditentukan pada penelitian ini menggunakan metode least square yaitu dengan perangkat $T_{-}$Tide. Prediksi tersebut didapatkan dengan cara menganalisa komponen pasang surut yang dihasilkan pada lokasi stasiun dengan menggunakan function t_predict yang tersedia di Matlab. Function tersebut dapat digunakan untuk memprediksi muka air pada masa lalu maupun masa yang akan datang (Pawlowicz, 2002). Pengolahan tersebut menghasilkan data prediksi pasang surut dengan interval waktu yang telah ditentukan sebelumnya.

\section{Validasi Data}

Metode yang digunakan untuk mengetahui keakuratan data hasil pengolahan pasang surut dengan metode least square dilakukan dengan cara membandingkan hasil yang diperoleh terhadap 
data lapangan. Keakuratan pada hasil pengolahan terhadap data lapangan dapat diketahui dalam presentase nilai melalui perhitungan nilai kesalahan relatifnya (RMSE). Apabila hasil presentase nilai error kecil dan perbandingan data pengolahan mendekati dengan data lapangan maupun data prediksi pasang surut, maka dapat dikatakan bahwa hasil pengolahan memberikan gambaran keadaan pasang surut sebenarnya yang ada di lapangan. Sedangkan hasil metode admiralty dan FFT akan dibandingkan nilainya terhadap hasil dari metode least square untuk mengetahui perbandingan hasil pengolahan dari metode-metode tersebut.

\section{HASIL DAN PEMBAHASAN}

\section{Metode Admiralty}

Pengolahan dengan metode admiralty ini menghasilkan nilai formzhal dan komponen utama pasang surut pada masing-masing bulan. Hasil tersebut menunjukkan nilai Formzhal pada stasiun Malahayati berkisar antara 0.087-0.245, sedangkan nilai formzhal rata-rata selama 72 bulan yaitu sebesar 0.18. Sehingga diketahui bahwa tipe pasang surut dari stasiun Malahayati berdasarkan metode admiralty adalah tipe pasang surut harian ganda. Dari hasil pengolahan data, selama periode 2013-2018 didapatkan nilai MSL dan HWL rata-rata sebesar $97.1 \mathrm{~cm}$ dan $199 \mathrm{~cm}$. Selain itu didapatkan juga 9 komponen utama pasang surut stasiun Malahayati dari tahun 2013-2018, yang disajikan pada Tabel 1. Dari tabel tersebut didapatkan komponen pasang surut yang dominan pada stasiun Malahayati merupakan komponen pasang surut semidiurnal yaitu M2 dan S2 dengan sebesar 46.584 dan 22.772 .

Tabel 1. Nilai Komponen Pasang Surut di Stasiun Malahayati, Banda Aceh Pada Tahun 20132018 Hasil Metode Admiralty

\begin{tabular}{cccccccccr}
\hline TAHUN & M2 & S2 & N2 & K1 & O1 & M4 & MS & K2 & P1 \\
\hline $\mathbf{2 0 1 3}$ & 42.663 & 25.639 & 10.066 & 8.319 & 3.444 & 0.635 & 0.51 & 6.923 & 42.663 \\
\hline $\mathbf{2 0 1 4}$ & 44.407 & 20.935 & 5.706 & 8.310 & 3.861 & 0.995 & $0.54:$ & 5.652 & 44.407 \\
\hline $\mathbf{2 0 1 5}$ & 50.461 & 23.212 & 8.943 & 7.816 & 3.865 & 0.935 & $0.74:$ & 6.267 & 50.461 \\
\hline $\mathbf{2 0 1 6}$ & 50.124 & 22.058 & 18.205 & 8.883 & 3.555 & 1.124 & 0.88 & 5.956 & 50.124 \\
\hline $\mathbf{2 0 1 7}$ & 45.838 & 22.315 & 8.128 & 9.757 & 3.495 & 1.221 & 0.81. & 6.025 & 45.838 \\
\hline $\mathbf{2 0 1 8}$ & 46.011 & 22.474 & 8.390 & 8.760 & 4.597 & 0.933 & $0.63 \vdots$ & 6.068 & 2.891 \\
\hline $\begin{array}{c}\text { RATA- } \\
\text { RATA }\end{array}$ & 46.584 & 22.772 & 9.906 & 8.641 & 3.803 & 0.974 & $0.68 i$ & 6.148 & 2.851 \\
\hline
\end{tabular}

\section{Metode Least Square}

Pengolahan data pasang surut dengan menggunakan metode ini hasilnya ditampilkan dalam beberapa grafik yang menggambarkan ketinggian air terhadap waktu pelaksanaan pengamatan. Dari pengolahan data tersebut juga diketahui beberapa kedudukan muka air laut di stasiun Malahayati selama 6 tahun, dimana rata-rata kedudukan muka air tersebut antara lain, yaitu: High water level (HWL) sebesar $219 \mathrm{~cm}$. Mean water level (MWL) sebesar $97 \mathrm{~cm}$ dan Lowest water level (LWL) sebesar $-24 \mathrm{~cm}$. Berdasarkan hasil analisis data pasang surut di stasiun Malahayati didapat nilai bilangan formzahl (F) yaitu sebesar 0.167. Sehingga diketahui bahwa tipe pasang surut dari stasiun Malahayati berdasarkan metode Least square adalah tipe harian ganda.

Pada hasil pengolahan pasang surut dengan menggunakan metode least square dilakukan perbandingkan terhadap data observasi yang disajikan dalam bentuk grafik (Gambar 2). Dari grafik tersebut didapatkan nilai RMSE sebesar 0.32 meter $(32 \mathrm{~cm})$. Dari hasil tersebut diketahui bahwa nilai 
RMSE hasil pengolahan dengan metode least square relative kecil, sehingga hasil tersebut dapat menggambarkan keadaan yang ada di lapangan.

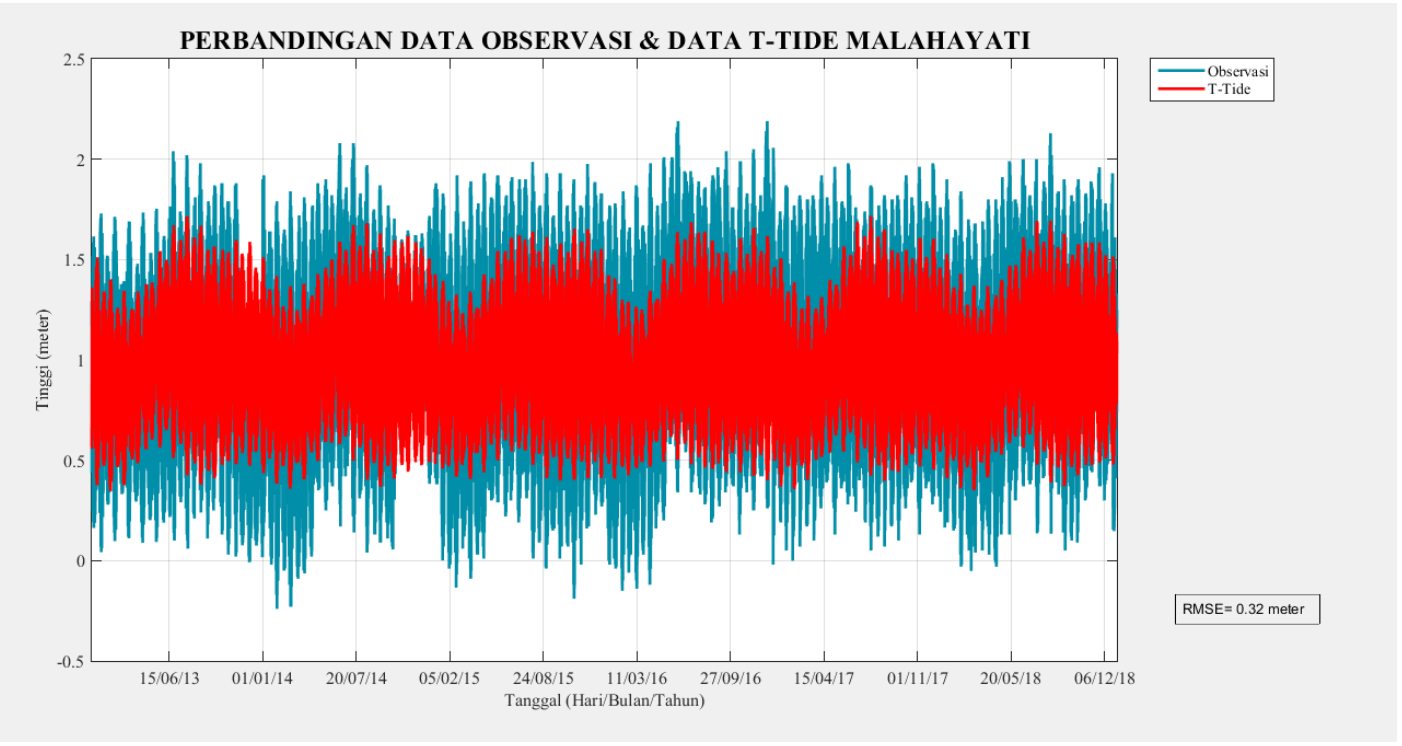

Gambar 2. Perbandingan data Observasi dan Prediksi di stasiun Malahayati

Untuk mengetahui keadaan pasang surut pada stasiun Malahayati pada waktu sebelum maupun sesudah observasi, maka dilakukan prediksi pasang surut dengan menggunakan paket $T$ Tide. Pada penelitian ini telah ditentukan waktu prediksi yaitu dalam rentang waktu 1 tahun dimulai tanggal 1 Januari 2019 pukul 00:00:00 sampai dengan tanggal 31 Desember 2019 pukul 23:45:00. Dari prediksi tersebut didapatkan grafik pasang surut selama waktu tersebut disertai dengan kedudukan permukaan air lautnya, yaitu nilai HWL (Highest Water Level) setinggi $174 \mathrm{~cm}$ dan nilai LWL (Lowest Water Level) setinggi $26 \mathrm{~cm}$.

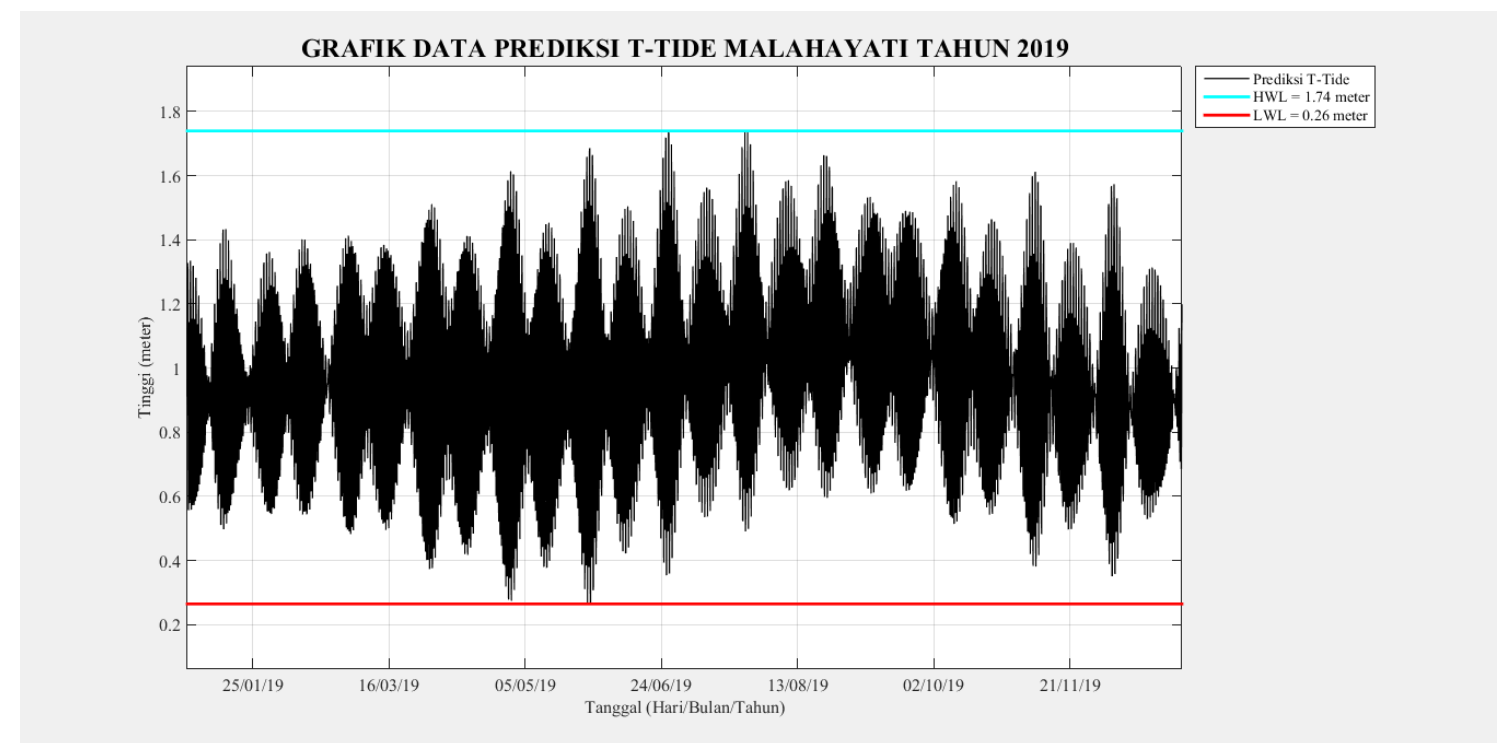

Gambar 3. Prediksi Pasang Surut di stasiun Malahayati, Banda Aceh tahun 2019 


\section{Metode Fast Fourier Transform}

Hasil pengolahan oleh metode FFT disajikan dalam bentuk grafik dan tabel. Berdasarkan hasil tersebut diketahui semua distribusi daya yang berpengaruh terhadap pembentukan pasang surut di stasiun Malahayati melalui frekuensi masing-masing komponen pasang surut. Gambar 4 merupakan periodogram dari sinyal pasang surut yang ada di stasiun Malahayati, dimana frekuensi yang ingin ditampilkan merupakan frekuensi yang muncul pada kurang dari 10 hari. Dalam menentukan frekuensi sendiri pada metode ini, sangat bergantung pada panjang data. Data yang digunakan menjadi batasan sejauh mana frekuensi yang akan didapatkan.

Hasil identifikasi dilakukan terhadap 21 komponen pasang surut meliputi komponen diurnal, semidiurnal dan komponen shallow water diantaranya yaitu: M2, K1, S2, O1, M1, N2, Q1, L2, 2N2, $\mathrm{J} 1$, OO1, dan P1. Dari hasil tersebut diketahui komponen pasang surut yang mendominasi pada stasiun Malahayati merupakan frekuensi yang relatif kecil dengan periode kurang dari 2 hari.

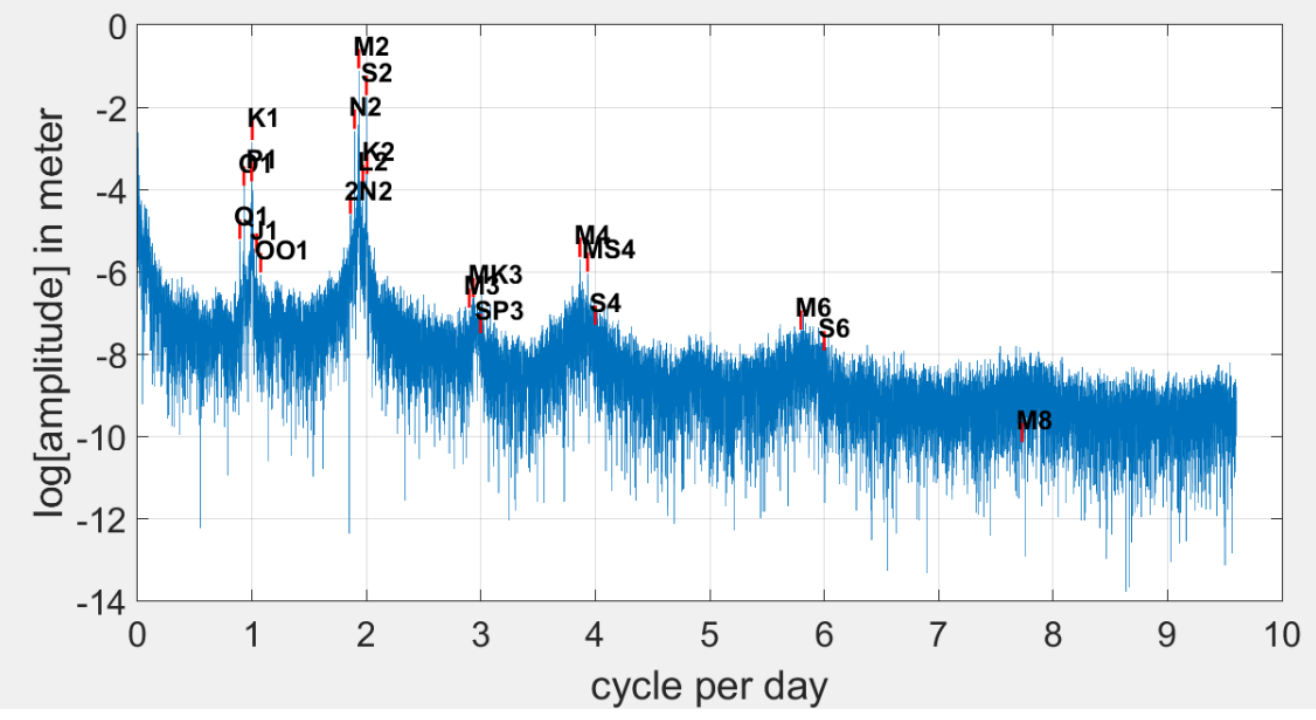

Gambar 4. Gambar hasil metode FFT data pasang surut stasiun Malahayati, Banda Aceh

Hasil tersebut menunjukkan bahwa dominansi dari sinyal pasang surut stasiun Malahayati oleh komponen semidiurnal yaitu M2 dan S2. Untuk mengetahui tipe pasang surut di stasiun Malahayati melalui metode FFT maka dilakukan perhitungan nilai formzhal menggunakan amplitudo dari komponen pasang surut tersebut. Hasil perhitungan nilai formzhal dengan metode FFT yaitu sebesar 0.162 , sehingga diketahui bahwa tipe pasang surut dari stasiun Malahayati berdasarkan metode FFT adalah tipe pasang surut harian ganda.

\section{Pembahasan}

Tipe pasang surut pada perairan disekitar Selat Malaka dan Laut Hindia menurut Wyrtki (1961) dan Pariwono (1989) adalah tipe harian ganda. Lokasi penelitian sendiri berada di perairan Selat Malaka. Dari beberapa penelitian yang telah dilakukan pada lokasi penelitian didapatkan hasil yang berbeda-beda. Penelitian yang dilakukan oleh Rahmat (2017) di perairan Malahayati mendapatkan hasil bahwa tipe pasang surut di perairan Malahayati adalah tipe harian ganda. Sedangkan pada penelitian Sitepu (2017) dan Fitriana (2019) bahwa perairan Malahayati memiliki tipe pasang surut campuran condong ke harian ganda.

Pasang surut di perairan Malahayati dipengaruhi oleh beberapa faktor di luar faktor astronomis. Faktor tersebut antara lain bahwa perairan Malahayati cenderung dangkal dan memiliki bentuk pantai setengah tertutup (teluk). Menurut Pariwono (1989) bahwa hal tersebut dapat memberikan 
pengaruh yang besar terhadap pola pasang surutnya. Menurut Nontji (2005) bahwa perairan pentai terutama di teluk atau selat yang sempit, mempengaruhi gerakan naik turunnya muka air yang dapat menimbulkan terjadinya arus pasut. Jika muka air bergerak naik, maka arus mengalir masuk, sedangkan pada saat muka air bergerak turun, arus mengalir ke luar. Sedangkan untuk pengaruh dasar perairan disampaikan oleh Kushadiwijayanto, et al (2017) dalam Lindawati (2018) bahwa gesekan dengan dasar perairan akan mengurangi kecepatan energi gelombang pasang surut. Kehilangan energi akibat gesekan dasar kemudian menyebabkan tinggi gelombang pasang surut akan terus berkurang.

Hasil pengolahan pasang surut dengan masing-masing metode memberikan nilai komponen pasang surut yang berbeda. Metode admiralty memberikan hasil meliputi 9 nilai komponen pasang surut utama (diurnal dan semidiurnal). Sedangkan pada metode least square memberikan hasil komponen yang paling banyak yaitu 68 komponen pasang surut yang meliputi komponen diural, semidiurnal dan komponen shallow water. Jumlah komponen yang dihasilkan dari pengolahan dengan menggunkan metode ini bervariasi, bergantung pada panjang data yang digunakan. Semakin panjang data yang digunakan maka semakin banyak jumlah komponen yang dapat diidentifikasi dan semakin didapatkan hasil yang dapat menggambarkan kondisi sebenarnya yang ada di lapangan (Herdia, 2016).

Pada pengolahan dengan metode FFT komponen pasang surut telah ditentukan sebelumnya. Dalam penelitian ini metode FFT menghasilkan 21 Komponen yang meliputi komponen diurnal, semidiurnal dan komponen shallow water. Tetapi jumlah tersebut dapat dikurangi maupun ditambahkan sesuai dengan yang diinginkan.

Untuk mengetahui dan menentukan nilai formzhal, komponen pasang surut dari masing-masing metode kemudian dihitung menggunakan rumus untuk mencari nilai formzhal. Perhitungan tersebut memberikan hasil yang tidak jauh berbeda (kurang dari 0.02). Metode admiralty menghasilkan nilai fomzhal sebesar 0.18 , metode least square 0.167 dan metode FFT sebesar 0.162. Dari ketiga metode hasilnya perairan stasiun Malahayati memiliki pasang surut tipe harian ganda.

Menurut Wyrrtki (1961) dan Pariwono (1989) tentang perairan di Indonesia, bahwa pasang surut ganda di Indonesia ditemukan terutama di Selat Malaka dan Lautan Hindia. Hasil yang diperoleh dari pengolahan menggunakan ketiga metode menunjukkan hasil yang sama bahwa perairan Malahayati memiliki tipe pasang surut harian ganda. Yang berarti bahwa terjadi 2 kali pasang dan 2 kali surut dengan tinggi yang hampir sama. Sehingga dapat dikatakan bahwa hasil yang diperoleh dapat menggambarkan keadaan yang ada di lapangan.

Dalam penelitian ini data pengukuran lapangan dibandingkan terhadap hasil pengolahan dengan metode least square. Tujuan dari perbandingan ini adalah untuk memvalidasi hasil pengolahan data yang telah dilakukan sehingga dapat diketahui keakuratan hasil pengolahan (Triatmodjo, 2009 dalam Budiwicaksono, 2013). Perbandingan ini melibatkan keseluruhan panjang data pengamatan dan data hasil pengolahan metode least square. Diketahui untuk nilai RMSE nya sebesar 0.32 meter $(32 \mathrm{~cm})$. Dari hasil tersebut didapatkan nilai yang relative kecil. Sehingga dapat dikatakan bahwa hasil dari pengolaha least square dapat memberikan gambaran keadaan pasang surut yang ada di lapangan.

Pada penelitian ini telah ditentukan waktu prediksi yaitu dalam rentang waktu 1 tahun dimulai tanggal 1 Januari 2019 pukul 00:00:00 sampai dengan tanggal 31 Desember 2019 pukul 23:45:00. Dari prediksi tersebut didapatkan grafik pasang surut selama waktu tersebut disertai dengan kedudukan muka airnya, yaitu nilai HWL (Highest Water Level) setinggi $174 \mathrm{~cm}$ dan nilai LWL (Lowest Water Level) setinggi $-26 \mathrm{~cm}$.

Untuk mengetahui keakuratan dari prediksi pasang surut yang dihasilkan, maka dilakukan validasi dengan cara membandingkan data prediksi dengan data lapangan, kemudian dari perbandingan tersebut akan didapatkan nilai RMSE nya (Gambar 3). Grafik tersebut memiliki rentang waktu 9 bulan, hal tersebut dikarenakan ketersediaan data lapangan pada tahun 2019 tidak memenuhi 1 tahun lamanya. Sehingga perbandingan yang dilakukan terhadap data prediksi juga hanya meliputi panjang data 9 bulan.

Dari grafik tersebut diketahui bahwa nilai RMSE yang dihasilkan relative kecil yaitu sebesar 0.64 meter. Walaupun terlihat grafik yang dihasilkan kurang memuaskan. Hal tersebut 
dimungkinkan terjadi karena pada data prediksi dilakukan dengan data lapangan pada tahun-tahun sebelumnya, dimana data tersebut tidak dapat dipastikan keadaanya sama dengan data pasang surut pada tahun 2019. Pada data prediksi yang dilakukan adalah mengasumsikan kondisi pasang surut yang terjadi pada tahun 2019 melalui analisis tahun-tahun sebelumnya. Selain itu, pada data lapangan sendiri diketahui banyak terjadi kekosongan data, yang mana telah dijelaskan sebelumnya, akan menambah nilai RMSE yang dihasilkan.

\section{KESIMPULAN}

Berdasarkan penelitian yang telah dilakukan didapatkan bahwa ketiga metode memberikan hasil tipe pasang surut pada stasiun Malahayati yaitu tipe pasang surut harian ganda. Dari pengolahan tersebut juga diketahui karakteristik pasang surut di lokasi stasiun meliputi komponen pasang surut diurnal, semidiurnal dan komponen shallow water. Komponen harmonik pembangkit pasang surut yang mempengaruhi pembentukan pasang surut di lokasi stasiun diketahui didominasi oleh komponen pasang surut semidiurnal yaitu M2 dan S2. Perbandingan hasil pengolahan pasang surut pada stasiun Malahayati yang diolah dengan menggunakan berbagai metode, yaitu metode admiralty, Least Square dan FFT memiliki hasil yang berbeda, tetapi nilai yang dihasilkan cenderung tidak jauh berberda. Perbedaan nilai formzhal yaitu kurang dari 0,02 sedangkan perbedaan nilai amplitude masing-masing komponen pasang surut kurang dari 0,1 meter.

\section{DAFTAR PUSTAKA}

Budiwicaksono R. A. 2013. Pemodelan pola arus tiga kondisi musim berbeda sebagai jalur pelayaran perairan teluk lampung menggunakan software DELFT3D. [skripsi]. Semarang: Ilmu Kelautan Universitas Diponegoro.

Fitriana, D., N. Oktaviani, I. U. Khasanah. 2019. Analisa Harmonik Pasang Surut Dengan Metode Admiralty Pada Stasiun Berjarak Kurang Dari $50 \mathrm{Km}$. Jurnal Meteorologi Klimatologi dan Geofisika. 6 (1)

Herdia, Adinda. 2016. Penentuan Datum Pasang Surut Di Pelabuhan Sadeng [skripsi]. Yogyakarta: Teknik Geodesi UGM

Lindawati, M. I. Jumarang, A. A. Kushadiwijayanto. 2018. Karakteristik Perambatan Gelombang Pasang Surut di Estuari Kapuas Kecil. Jurnal Laut Khatulistiwa. 1(3): 61-66

Pariwono, J.I. 1989. Kondisi Pasang Surut di Indonesia. Kursus Pasang Surut.

P3O-LIPI: Jakarta.

Pawlowicz, R. Bob Beardsley and Steve Lentz. 2002. Classical Tidal Harmonic Analysis Including Error Estimates in Matlab Using T Tide. Computers \& Geosciences. 28:929-937930

Purwanto, Bambang. 2017. Ruang Maritim Di Sisi Barat Pulau Sumatera Yang Diabaikan, Sebuah Tinjauan Historiografis. Paramita: Historical Studies Journal, 27 (2): 212-228

Rahmat, F.B., Siddhi Saputro dan Gentur Handoyo. 2017. Analisa Laju Sedimentasi Diteluk Krueng Raya dan Sekitarnyakabupaten Aceh Besar. Jurnal Oseanografi. 6 (3): 485-493

Sitepu, R. S., S. Saputro, A. Satriadi. 2017. Studi Sebaran Sedimen Dasar Di Teluk Krueng Raya Dan Sekitarnya. Jurnal Oseanografi. 6 (4):625 - 632

Syahputra, Henry dan R. Bambang Aditya Nugraha. 2016. Analisis Perbandingan Akurasi Model Prediksi Pasang Surut: Studi Kasus di Selat Larantuka, Flores Timur, Nusa Tenggara Timur. Jurnal Maspari

Wyrtki, Klaus. 1961. Physical Oceanography of the Southeast Asian Waters. The University of California, Scripps Institution of Oceanography Lajolla: California. 